\title{
A re community structures of soil nematodes different between organic and conventional farming systems in commercial tomato fields?
}

\author{
Hiroaki Okada ${ }^{1,2}$, Hiroshi Hasegawa3 ${ }^{3}$, Tomoyoshi Hashimoto ${ }^{3}$, \\ Hiroyuki Sekiguchi ${ }^{3}$ and Yasufumi U rashima ${ }^{3}$
}

\begin{abstract}
Compared with studies conducted in experimental crop fields, those in commercial fields have been very limited to examining how organic (ORG) and conventional (CONV) farming systems differ in their effects on biological and physicochemical characteristics of soils. To evaluate practical effects of ORG systems, a comparison is essential with "practical" CONV systems where organic amendments are also used in addition to chemical fertilizers and pesticides. We compared nematode community structures between the two systems for commercial tomato production in greenhouses located in northern Japan in 2005 and 2006. We examined if the farming system was still influential even when differences in soil texture, study plot locations and growing seasons among the plots were considered. The density of the predator-omnivore group, with Dorylaimida as the dominant taxon, and Structure Index were always significantly affected by farming system, and their values were greater in ORG. Redundancy analysis in 2005 revealed that farming system could significantly explain the whole community structure, and determined Dorylaimida as an indicator for ORG, while Diplogasteridae and A nguinidae were indicators for CONV. Although redundancy analysis could not significantly explain community structure with farming system in 2006, Dorylaimida and Diplogasteridae were still good indicators for the two systems. Individual variables, such as soil texture and bacterial density, were found to have significant effects on the two nematode taxa, although we could not interpret sufficiently the causal relationships. Further studies should include other measurements such as chemical pesticides applied for better interpretation of the differences between these systems. Nematol. Res. 39 (2), $63-71$ (2009).

Key words : predator-omnivore group, Structure Index.
\end{abstract}

\section{INTRODUCTION}

Recently in Japan organic farming and produce are drawing consumers' attention more and more, with the help of governmental support. For scientific evaluation of an organic farming system, however, it is important to know how the system affects ecosystems in and around crop fields under the system. Several studies have examined if soil microbial and nematode community structure showed some differences between organically and conventionally managed fields (Briar et al., 2007; Bulluck et al., 2002; Ferris et al., 1996; T siafouli et al., 2006; Wang et al., 2006). A ctually, most of these studies compared effects of organic amendments and chemical fertilizers applied to experimental field plots. In commercial crop fields, however, it is not realistic to expect that no organic amendments will be applied in any type of farm management including a "conventional" one. A ccordingly, actual differences should be examined between ORG, organic amendments without

${ }^{1}$ National Institute for A gro-Environmental Sciences, 3-1-3 Kan'nondai, T sukuba, Ibaraki, 305-8604, Japan.

${ }^{2}$ Corresponding author, e-mail: hokada@ affrc.go.jp

${ }^{3}$ National A griculture and Food Research Organization, 3-1-1 Kan'nondai, T sukuba, Ibaraki, 305-8517, Japan. chemical fertilizers and pesticides, and CONV, organic amendments with chemical fertilizers and pesticides. Some studies compared the soil physicochemical and biological characteristics in commercial fields (Liu et al., 2007; Sekiguchi et al., 2008; Taki and Kato, 1998). Nevertheless, only a few studies in different areas of the world (Mulder et al., 2003; Neher, 1999) and none in Japan have examined nematode community structures in commercial crop fields. Nematode community analyses are useful in assessing soil ecosystem status and function, because nematodes are ubiquitous, easy to sample and easy to classify into feeding groups or functional guilds (Ferris and Bongers, 2006; Neher, 2001; Y eates, 2003; $Y$ eates and Bongers, 1999). A $n$ additional advantage of using the nematode community is that these animals are likely to be more liable to chemical pesticides (Pen-Mouratov and Steinberger, 2005; Y ardirn and $E$ dwards, 1998), than microbiological or physicochemical characteristics of soils. To interpret easily what can be inferred from nematode community structures for soil ecosystem conditions, several indices (weighted means), such as the Maturity Index (Bongers, 1990) and Structure Index (Ferris et al., 2001), have been developed and used in many soil ecological studies (Bongers, http://www. 
nem.wur.nl/ UK/Research/M aturity +index/). How ever, application of these indices is still limited in Japan to a few studies, and they were not conducted in commercial fields but in experimental ones (Okada et al., 2004, Okada and Harada, 2007; T akeda et al., 2009).

It is a challenge to conduct studies in commercial fields for the analysis of causal relationships between biological phenomena and environmental variables. The variables including soil texture, field location and growing season, may not be of scientific interest but may affect analytical results and vary among field plots, thus interpretation and evaluation of the obtained results are sometimes difficult. In our previous studies of microbial characteristics in commercial tomato greenhouses of ORG and CONV farming systems, the location and growing season were different among the greenhouse plots, but these factors were not considered, and sometimes we failed to detect differences between the two systems (Sekiguchi et al., 2008; U rashima et al., 2009). In this study we examined whether or not nematode community structures are influenced by ORG or CONV farming systems in the same plot set, even when taking the effects of soil texture, location and growing sea- son into consideration.

\section{MATERIALS AND METHODS}

Study site, sample collection and nematode analysis:

T wenty-one greenhouses in Y amagata and Fukushima Prefectures in the Tohoku region of Japan were used as field plots in 2005 and 2006 (T able 1). Plots of the normal growing season were surveyed in June, and plots of the late season in A ugust. In each plot at least two planting beds were sampled. The details of the sampling procedure have already been reported elsewhere (Sekiguchi et al., 2008). Briefly, four scoops of soil ( $15 \mathrm{~cm}$ depth) at 4-5 m intervals on each bed were taken to obtain a composite sample from each plot. Soil samples were passed through a 5-mm mesh screen to remove gravel and roots, then gently hand-mixed. A modified Baermann funnel method using trays instead of funnels was employed for the extraction of nematodes from $100 \mathrm{~g}$ fresh soil. The details of the extraction procedure, nematode specimen preparation and community analysis have already been reported in Okada et al. (2004) and Okada and Harada (2007). Briefly, the extracted nematodes were counted to estimate density per $100 \mathrm{~g}$ dry soil, then

Table 1. Farming systems, locations, sampling dates and management summaries of tomato greenhouses used as field plots. ${ }^{1}$

\begin{tabular}{|c|c|c|c|c|c|c|c|}
\hline \multirow{2}{*}{ System } & \multirow{2}{*}{ City or town } & \multirow{2}{*}{ Prefecture } & \multicolumn{2}{|c|}{ Sampling date ${ }^{2}$} & \multirow{2}{*}{ Main types of organic fertilizer } & \multirow{2}{*}{$\begin{array}{l}\text { Synthetic } \\
\text { fertilizer use }\end{array}$} & \multirow{2}{*}{$\begin{array}{c}\text { Chemical } \\
\text { pesticide use }\end{array}$} \\
\hline & & & 2005 & 2006 & & & \\
\hline CONV & Yonezasa city & Yamagata & June 22 & June 14 & Fermented compost & Yes & Yes \\
\hline CONV & Yonezasa city & Yamagata & June 22 & June 14 & Cattle feces manure & Yes & No \\
\hline CONV & Yonezasa city & Yamagata & June 22 & June 14 & Rapeseed meal, fermented compost & Yes & Yes \\
\hline CONV & Shiokawa town & Fukushima & June 21 & June 15 & Cattle feces manure with momicara & Yes & Yes \\
\hline CONV & Shiokawa town & Fukushima & June 21 & June 15 & Pig feces manure with momicara & Yes & Yes \\
\hline CONV & Shiokawa town & Fukushima & June 21 & June 15 & Pig feces manure with momicara & Yes & Yes \\
\hline CONV & Shiokawa town & Fukushima & June 21 & June 15 & Pig feces manure with momicara & Yes & Yes \\
\hline CONV & Shiokawa town & Fukushima & June 21 & June 15 & Pig feces manure with momicara & Yes & Yes \\
\hline CONV & Shiokawa town & Fukushima & June 21 & June 15 & Cattle feces manure with momicara & Yes & Yes \\
\hline CONV & Shiokawa town & Fukushima & June 21 & June 15 & Cattle feces manure with momicara & Yes & Yes \\
\hline CONV & Shiokawa town & Fukushima & June 21 & June 15 & Cattle feces manure with momicara & Yes & Yes \\
\hline CONV & Shiokawa town & Fukushima & June 21 & June 15 & Cattle feces manure with momicara & Yes & Yes \\
\hline CONV & Yonezasa city & Yamagata & June 22 & Aug. 1 & Commercial fertilizer, rice straw and momicara & ra Yes & Yes \\
\hline ORG & Kawanishi town & Yamagata & June 22 & June 14 & Rice bran, fish meal, fermented compost & No & No \\
\hline ORG & Aidsuwakamatsu city & Fukushima & June 21 & June 15 & Food residue compost & No & No \\
\hline ORG & Aidsuwakamatsu city & Fukushima & June 21 & June 15 & Fermented compost & No & No \\
\hline ORG & Yonezasa city & Yamagata & Aug. 11 & Aug. 1 & Fermented compost & No & No \\
\hline ORG & Yonezasa city & Yamagata & Aug. 11 & Aug. 1 & Commercial organic fertilizer & No & No \\
\hline ORG & Kawanishi town & Yamagata & Aug. 11 & Aug. 1 & Rice bran, fish meal, fermented compost & No & No \\
\hline ORG & Yonezasa city & Yamagata & Aug. 11 & - & Unknown compost & No & No \\
\hline ORG & Yonezasa city & Yamagata & Aug. 11 & - & Unknown compost & No & No \\
\hline
\end{tabular}

${ }^{1}$ Fertilizer and pesticide types were unclear for some plots, but organic (ORG) plots certified by organic JA S (Japan A gricultural Standards), used no chemical fertilizer or pesticide. Conventional (CONV) plots used both organic and chemical fertilizers. All plots had been growing tomatoes for at least two years before 2005. Some plots grew other crops such as spinach, leaf vegetables of Brassica, before and after tomato cultivation.

2 Plots surveyed in June adopted normal season growing, and those in A ug. adopted late growing.

${ }^{3}$ Chemical pesticides used in CONV plots were acephate, neonicotinoid, chlorphenapyr, triflumizole, thiophanate-methyl, etc. 
fixed in TAF and transferred to anhydrous glycerol prior to being mounted on glass slides for observation. The first 100 individuals encountered were identified to family or generic level to estimate densities of feeding groups as classified mainly according to Okada and Harada (2007) into bacterial feeders (BAC), fungal feeders + facultative root feeders ( $F F R$ ), predators + omnivores (PROM), obligatory root feeders $(O R F)$, and total density (ALL). Then community indices and diversity indices were calculated (T able 2).

Microbial analysis and physicochemical characteristics of the soils:

To determine what types of soil biological and physicochemical characteristics (environmental variables) were affecting nematode community structures, the following measurements and analyses were conducted. To estimate bacterial (Bac, including actinomycetes) and fungal (Fun) densities, a dilution plating technique (PL) was used to determine the number of colony forming units (CFU) per $1 \mathrm{~g}$ dry soil. Detailed methodology is described in Sekiguchi et al. (2008). Soil phospholipid fatty acid measurements are also commonly used as microbial indicators (F rostegård et al., 1993; Bossio et al., 1998). In this study, molar percentages of the fatty acid of gram negative (PLgn) and positive bacteria (PLgp), actinomycetes (PLac) and fungi (PLfu), together with the total amount of the fatty acid (PLFA, $\mathrm{mg} / 1,000 \mathrm{~kg}$ dry soil), were also used as microbial variables. The PLFAs were analyzed in duplicate using $10 \mathrm{~g}$ (wet wt) of soil according to the one-phase extraction method of A rao et al. (1998). Lipid extracts were evaporated to dryness under nitrogen, dissolved in $100 \mu \mathrm{l}$ of chloroform and applied to silica Sep-Pak ${ }^{\top M}$ columns. The column was eluted with $10 \mathrm{ml}$ chloroform, $10 \mathrm{ml}$ acetone and $6 \mathrm{ml}$ methanol in turn. Each column elutant was considered to correspond to the neutral lipid, glycolipid and phospholipid fractions, respectively. Fatty acid methyl esters were prepared from the phospholipid fraction by methanolysis using 3\% HCl-methanol. GC-MS measurements were conducted on a QP-5000 (Shimadzu Corp.). The physicochemical characteristics of the soils have already been reported in Sekiguchi et al. (2008).

Statistical analysis:

First, to examine if farming system (ORG or not) affected nematode density and community indices, a GLM (generalized linear model) procedure and F-test were conducted for log-transformed feeding-group densities, community indices and diversity indices. In the procedure, standardized ratios of sand ("sand") and silt ("silt") of soils, and binary data of location (Fukushima or Y amagata Prefecture, "location") and growing season (normal or late, "season") were also used as explanatory variables for nematode characteristics, to determine if the farming system (binary data: ORG or not) still had significant effects independent of these variables. The same analysis was conducted for $\mathrm{Bac}$ because it was found to significantly affect some nematode taxa as revealed by the following analysis. Second, RDA (redundancy analysis) was conducted using log-transformed densities of nematode taxa (family or genus) which occurred in four or more plots, to examine if farming system (ORG or not) can explain the whole nematode community structure. Nematodes of the order Dorylaimida are usually not abundant in annual crop fields, but are important indicators of soil ecosystem disturbance (Bongers, 1990), thus we treated all their taxa together as "Dorylaimida" in this study. In the analysis, system was used as a single explanatory variable, while sand, silt, location, and season were designated as co-variables to remove their effects on nematodes. Third, when the system failed to significantly explain the whole nematode community structure, stepwise multiple-regression was conducted for each of the nematode taxa possibly representing ORG or CONV, with system, sand, silt, location, and season as explanatory variables. Finally, to determine specific environmental variables

Table 2. Nematode community indices and diversity indices used.

\begin{tabular}{|c|c|c|c|}
\hline & Index & Objective of assessment & Unit of groupings used ${ }^{1}$ \\
\hline MI & M aturity Index (Bongers, 1990) & Disturbance in general & Groups of free living taxa based on cp scores \\
\hline MI2-5 & M aturity Index 2-5 (Bongers and Korthals, 1993) & Long-term disturbance in general & Groups of freeliving taxa without $\mathrm{cp} 1$ \\
\hline$\Sigma \mathrm{MI}$ & Combined maturity index (Yeates, 1994) & Disturbance in general & Groups of free living and plant parasitic taxa \\
\hline$\Sigma M \mid 2-5$ & Combined maturity index 2-5 (Yeates, 1994) & Long-term disturbance in general & Groups of free living and plant parasitic taxa without $\mathrm{cp} 1$ \\
\hline $\mathrm{Cl}$ & Channel Index (Ferris et al., 2001) & Biomass ratio of fungi to bacteria & Functional guilds ( $\mathrm{BACl}$ and $\mathrm{FFR2}$ ) \\
\hline El & Enrichment Index (Ferris et al., 2001) & Soil enrichment or fertility & Functional guilds (BAC1, 2 and FFR2) \\
\hline $\mathrm{SI}$ & Structure Index (Ferris et al., 2001) & Food web development & Functional guilds without $\mathrm{BACl}$ and $\mathrm{ORF} 2-5$ \\
\hline$H^{\prime}$ & Shannon-W iener's index & Diversity & Every taxon \\
\hline$\beta$ & Inverse of Simpson's index & Diversity & Every taxon \\
\hline$S$ & Species richness (number of taxa found) & Diversity & Every taxon \\
\hline
\end{tabular}

${ }^{1}$ For cp scores and functional guild abbreviations, see Table 3 . 
which affected significantly the selected nematode taxa, stepwise multipleregression was again conducted, with the following physicochemical and microbial characteristics of soils as explanatory variables, together with sand, silt, location, and season, after standardization: bulk density (BD), $\mathrm{pH}$, phosphate absorption coefficient (PAC), CEC (me/100 $\mathrm{g})$, amounts $(\mathrm{mg} / \mathrm{100} \mathrm{g})$ of $\mathrm{CaO}, \mathrm{K} 2 \mathrm{O}, \mathrm{MgO}$, available phosphorus $(\mathrm{P}), \mathrm{NO}_{3}-\mathrm{N}\left(\mathrm{NO}_{3}\right)$, and $\mathrm{NH}_{4}-\mathrm{N}\left(\mathrm{NH}_{4}\right)$, ratios of total carbon $(\mathrm{T}-\mathrm{C})$ and nitrogen $(\mathrm{T}-\mathrm{N})$, and bacterial $(\mathrm{BaC})$ and fungal (Fun) CFU, PLgn, PLgp, PLac, PLfu, and PLFA. The GLM procedure, and F-test were conducted by the statistical package "R" (R Development Core T eam, 2005), RDA by CA NOCO ${ }^{\mathrm{TM}}$ Version 4.5 (Microcomputer Power, NY, USA), and multiple regression by JM PTM Version 5 (SA S Institute Japan).

\section{RESULTS}

In the field plots, 27 nematode taxa were found ( $T$ able 3). A mong feeding groups, PROM was always significantly affected by farming system $(P<0.05)$, and was greater in ORG than in CONV (Table 4). Conversely although not significant, ORF density was greater in CONV. A mong the community indices examined, Structure Index (SI) was always significantly affected by farming system $(P<0.05)$, and was greater in ORG. Maturity Index (MI) and its relative indices were generally greater in $O R G$, but differences were not al ways significant. RDA showed that farming system could significantly $(P<0.05)$ explain whole community structure in 2005 (Fig. 1), and the density of Dorylaimida was significantly greater in ORG, while Diplogasteridae and A nguinidae were greater in CONV (T able 5). In 2006, farming system failed to explain significantly $(P>0.05)$ the whole structure, according to RDA (graph not shown). However, multiple regression models for individual nematodes predicted that Dorylaimida, Diplogasteridae and A nguinidae were in line with the results in 2005, although the model for Anguinidae was not significant $(P>0.05$, Table 5). A nother multiple regression model suggested that

Table 3. Nematode taxa found in the study. The classification of feeding groups and cp scores were according to Yeates et al. (1993), B ongers and Bongers (1998), Bongers (1990) and Okada and Harada (2007).

\begin{tabular}{|c|c|c|c|}
\hline Feeding group & Taxon & Family & Cp score \\
\hline BAC & Diplogasteridae & Diplogasteridae & 1 \\
\hline \multirow[t]{10}{*}{ (Bacterial feeder) } & Diploscapter & Diploscapteridae & 1 \\
\hline & Eumonhystera & Monhystreidae & 1 \\
\hline & Panagrolaimidae & Panagrolaimidae & 1 \\
\hline & Rhabditidae & Rhabditidae & 1 \\
\hline & A crobeloides & Cephalobidae & 2 \\
\hline & Drilocephalobus & Osstellidae & 2 \\
\hline & Plectus & Plectidae & 2 \\
\hline & Cylindrolaimus & Diplopeltidae & 3 \\
\hline & Prismatolaimus & Prismatolaimidae & 3 \\
\hline & A laimus & Alaimidae & 4 \\
\hline FFR & A nguinidae & Anguinidae & 2 \\
\hline (Fungal feeder+ & A phelenchus & A phelenchidae & 2 \\
\hline \multirow[t]{3}{*}{ Facultative root feeder) } & A phelenchoides & A phelenchoididae & 2 \\
\hline & Filenchus & Tylenchidae & 2 \\
\hline & Boleodorus & Tylenchidae & 2 \\
\hline PROM & A chromadora & A chromadoridae & 3 \\
\hline \multirow[t]{7}{*}{ (Predators+Omnivores) } & Coomansus & Mononchidae & 4 \\
\hline & M ylonchulus & Mononchidae & 4 \\
\hline & Qudsianematinae & Qudsianematidae & 4 \\
\hline & Nygolaimidae & Nygolaimidae & 5 \\
\hline & A porcelaiminae & A porcelaimidae & 5 \\
\hline & Laimydorinae & Thornenematidae & 5 \\
\hline & Opisthodorylaimus & Thornenematidae & 5 \\
\hline ORF & H eterodera & Heteroderidae & 3 \\
\hline \multirow[t]{2}{*}{ (Obligatory root feeder) } & M eloidogyne & Meloidogynidae & 3 \\
\hline & Pratylenchus & Pratylenchidae & 3 \\
\hline
\end{tabular}


Table 4. Effects ${ }^{1}$ of farming system (ORG and CONV) on density , community indices and diversity indices of nematodes, and microbial characteristics.

\begin{tabular}{|c|c|c|c|c|c|}
\hline & & \multicolumn{2}{|c|}{2005} & \multicolumn{2}{|c|}{2006} \\
\hline & & ORG & CONV & ORG & CONV \\
\hline Nematode density ${ }^{2}$ & $A L L$ & 6338.3 & 4611.4 ns & 4966.7 & 5081.4 ns \\
\hline \multirow[t]{4}{*}{ (/100g dry soil) } & BAC & 3148.6 & 3004.4 ns & 3111.7 & 3023.2 ns \\
\hline & FFR & 1451.9 & $943.3 \mathrm{~ns}$ & 1019.3 & 1220.6 ns \\
\hline & PROM & 233.3 & $2.2 *$ & 93.2 & $4.4 *$ \\
\hline & ORF & 1.5 & $37.3 \mathrm{~ns}$ & 4.7 & $14.9 \mathrm{~ns}$ \\
\hline \multirow[t]{10}{*}{ Nematode index } & MI & 2.03 & $1.55 *$ & 1.76 & $1.55 \mathrm{~ns}$ \\
\hline & $M I 2-5$ & 2.48 & $2.08 *$ & 2.32 & $2.07 \mathrm{~ns}$ \\
\hline & $\Sigma \mathrm{Ml}$ & 2.05 & 1.62 ns & 1.78 & $1.67 \mathrm{~ns}$ \\
\hline & $\Sigma M I 2-5$ & 2.49 & $2.16 \mathrm{~ns}$ & 2.34 & $2.19 \mathrm{~ns}$ \\
\hline & $\mathrm{Cl}$ & 27.16 & $18.22 \mathrm{~ns}$ & 17.46 & 19.90 ns \\
\hline & EI & 70.78 & $79.30 \mathrm{~ns}$ & 78.18 & 78.86 ns \\
\hline & SI & 39.62 & $10.44 *$ & 30.69 & $10.84 *$ \\
\hline & $H^{\prime}$ & 2.23 & $2.59 \mathrm{~ns}$ & 2.22 & $2.44 \mathrm{~ns}$ \\
\hline & $\mathrm{S}$ & 7.63 & $9.46 \mathrm{~ns}$ & 8.17 & $9.00 \mathrm{~ns}$ \\
\hline & $\beta$ & 4.09 & $5.69 \mathrm{~ns}$ & 3.89 & $4.78 \mathrm{~ns}$ \\
\hline $\begin{array}{l}\text { Microbial characteristics } \\
\text { (CFU/g dry soil) }\end{array}$ & $\mathrm{Bac}$ & $4.6 \mathrm{E}+08$ & $3.6 \mathrm{E}+08 *$ & $1.6 \mathrm{E}+08$ & $1.1 \mathrm{E}+08 \mathrm{~ns}$ \\
\hline
\end{tabular}

${ }^{1}$ Values with * indicate farming system was significant in GLM - setpA IC and F - test $(P<0.05)$ procedures with farming system, sand, silt, location and season as explanatory variables.

2 Log-transformed to improve inequality of variances.

Table 5. Effects of farming system on the densities of the selected nematode taxa

\begin{tabular}{lccc}
\hline & $\begin{array}{c}\text { Coordinates for t-value } \\
\text { biplot in RDA , 20051 }\end{array}$ & \multicolumn{2}{c}{$\begin{array}{c}\text { Effects of system in regression } \\
\text { model, 2006 }\end{array}$} \\
\cline { 3 - 4 } & & Coefficient & $\mathrm{P}$ \\
\hline System & 0.3853 & - & - \\
Dorylaimida & 0.2428 & positive & 0.0145 \\
Diplogasteridae & -0.2589 & negative & 0.0479 \\
A nguinidae & -0.2193 & negative & 0.1648 \\
\hline
\end{tabular}

${ }^{1}$ Nematode taxon with smaller absolute value than 0.3853 is significantly predicted by system.

2 Regression models included system, sand, silt, location and growing season as explanatory variables.

Table 6. Regression models for the selected taxa representing farming systems.

\begin{tabular}{|c|c|c|c|c|c|}
\hline System & Taxon & Year & Regression model ${ }^{1}$ & $\begin{array}{l}\text { A djusted } \\
\text { R square }\end{array}$ & $P$ \\
\hline \multirow[t]{2}{*}{ ORG } & Dorylaimida & 2005 & $-213.6(P L g p b)+51(P L a c)+56.4($ sand $)$ & 0.4553 & 0.0038 \\
\hline & & 2006 & 41.5(sand) & 0.2367 & 0.0201 \\
\hline \multirow[t]{2}{*}{ CONV } & Diplogasteridae & 2005 & $-123(\mathrm{Bac})+100.1(\mathrm{PL} \mathrm{gpb})+114.8\left(\mathrm{NO}_{3}\right)-43.3(\mathrm{Ca})+63.1($ silt $)+4.6$ (location)-2.5(season) & 0.8810 & $<.0001$ \\
\hline & & 2006 & $-30(\mathrm{Bac})+146.4(\mathrm{PL} \mathrm{gnb})-144.6(\mathrm{pH})+67.9(\mathrm{P})-33($ sand $)$ & 0.6062 & 0.0030 \\
\hline
\end{tabular}

${ }_{1}$ Objectves, log-transformed nematode density /100 g dry soil, were regressed to standardized explanatory variables by using stepwise procedure with selection criteria of $P=0.25$. For Dorylaimida, 2006, the criteria was $P=0.20$ because too many $(7<)$ variables were selected at $P=0.25$.

For abbreviations of variables, see text. 


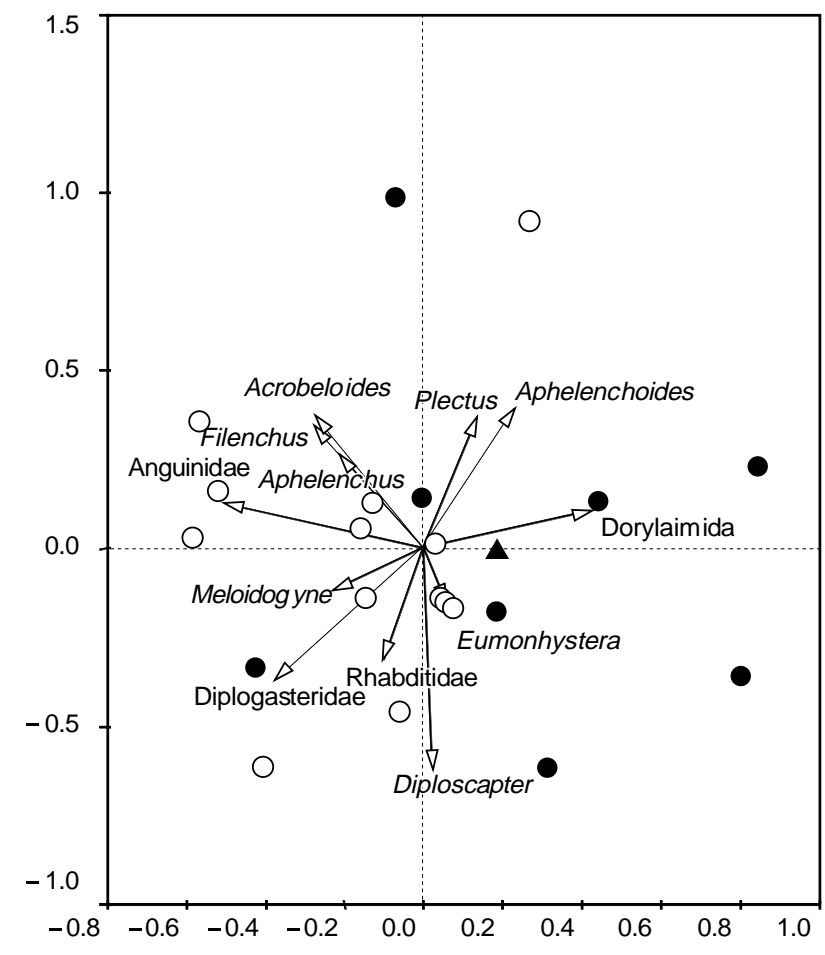

Fig. 1. RDA triplot graph of study plots (ORG, black; CONV, white dot), nematode taxa, and farming system (black triangle), 2005, with sand, silt, location and growing season as co-variables. Cumulative \% variance of species was 21.1 , and the cannonical axis was significant $(P=0.006)$. In 2006 , the axis was not significant $(P=0.36$, graph not show $n)$.

one to seven explanatory variables were affecting Dorylaimida and Diplogasteridae (T able 6). A mong the variables, some were always affecting the nematodes in the same direction, e.g., sand for Dorylaimida and Bac for Diplogasteridae. Bac tended to be greater in ORG than in CONV, although farming system effects were not always significant (T able 4).

\section{DISCUSSION}

To evaluate if an organic farming (ORG) system can affect soil biological characteristics, we used nematodes as representatives of the organisms in soil because of their advantages as indicators (they are ubiquitous, sensitive to chemical pesticides, easy to sample and easy to classify into functional guilds, Bongers, 1990; Ferris et al., 2001). Our study revealed that farming system always affected nematode community characteristics, even when soil texture, field plot location and growing season were taken into consideration, as shown by greater predators + omnivores (PROM) density and Structure Index (SI) values in ORG. Maturity Index (MI) and Maturity Index 2-5 (MI2-5) were also greater in ORG, although not significant in 2006. The reduced number of ORG plots (six) may have caused unclear results of the year. Considering that diversity indices were not greater in ORG, the greater $\mathrm{MI}$ and SI values can be attributed to greater PROM density, rather than development of a complex food web. Examination of the whole community structure also showed that farming system significantly affected the structure, and Dorylaimida, Diplogasteridae and A nguinidae represented the two systems in 2005. A lthough the farming system did not explain community structure significantly in 2006, Dorylaimida and Diplogasteridae were each affected by the farming system in the year. Multiple regressions showed that both physicochemical and microbial characteristics affected these nematode taxa. Unfortunately, however, only a few of these variables were consistently influential, thus examination of causal relationships should be limited.

Dorylaimida with cp score of 4-5 accounted for as much as $87 \%$ (2006) - $99 \%$ (2005) of the PROM group, and this taxon could be most responsible for the consistently greater PROM density, $\mathrm{MI}$ and its relatives, and $\mathrm{SI}$ in ORG. For this taxon, sand always had a significant effect. This is a reasonable result because Dorylaimida, relatively large-sized nematodes (average body size is a little over $1 \mathrm{~mm}$, the largest is $12 \mathrm{~mm}$, according to Jairajpuri and A hmad (1992), tend to predominate in sandy habitats such as sand dunes (Goralczyk , 1998; Wall et al., 2002). A ctually, our previous survey revealed that ORG soils contained more sand than conventional farming (CONV, Sekiguchi et al., 2008). In 2005 for Dorylaimida, phospholipid fatty acid \% of gram positive bacteria (PLgpb) and actinomycetes (PLac) also had a significant effect. To our knowledge, however, no study is available that explains the relationships of grampositive bacteria and actinomycetes, to the nematode taxon. From the point of CONV system, a possible explanation for the paucity of Dorylaimida is the suppression of the nematodes by chemical pesticides, and their residues and degradation products (M oser et al., 2004), together with chemical fertilizers releasing ammonia in soil. Further studies are needed to evaluate their effects. The CONV "indicator", Diplogasteridae, was negatively affected by bacterial density (Bac). This is in accordance with the fact that Bac tended to be smaller in CONV. Considering the microbivorous habits of these nematodes, this result was difficult to interpret. A possible explanation was that some antagonistic bacteria suppressing these nematodes were fewer in CONV.

Quite a few studies have reported differences in nematode community structures between managed systems, but most of these studies examined soils in experimental fields, where the system differences can be attributed mainly to those between organic amendments and chemical fertilizers. In order to evaluate practical effects of systems, the nematode communities in commercial fields should be 
examined, where organic amendments, chemical fertilizers and chemical pesticides are all used together under the CONV system. Exceptionally, Mulder et al. (2003) examined commercial farms in Dutch grasslands whose systems ranged from certified organic to intensive farming with chemical fertilizers and pesticides. They found that nematode community diversity was influenced by soil pH and livestock density. Neher and Olson (1999) compared ORG and CONV commercial farms of annual crops, although crop species were not always the same. They found that Criconematidae, Heteroderidae, Plectidae, Prismatolaimidae, and Tylencholaimidae had greater densities in ORG than in CONV, but they did not mention the causal factors. Different from our study, they did not find any significant differences in MI, $\Sigma$ MI, diversity indices and feeding group densities between the system types. Reportedly for the other biological, or physicochemical soil characteristics, some differences between commercial ORG and CONV systems were found. Taki and Kato (1998) found a trend in that $\mathrm{T}-\mathrm{C}, \mathrm{T}-\mathrm{N}, \mathrm{CEC}$, water-stable aggregates ratio, water retentivities, plastic limit, soil animal abundance (e.g. earthworms), $\mathrm{CO}_{2}$ emission, enzyme activities, and quinone amount and its diversity were greater, while solid phase ratios were smaller, in ORG than in CONV in Japan, although their statistical analyses were not sufficient. Liu et al. (2007) found that soils from organic farms had improved soil chemical factors and higher levels of extractable $\mathrm{C}$ and $\mathrm{N}$, higher microbial biomass carbon and nitrogen, and net mineralizable $\mathrm{N}$ in the US. In addition, soil microbial respiration was higher in soils from organic than from sustainable or conventional farms, indicating that microbial activity was greater in the organic soils. Similarly, our current and previous (Sekiguchi et al., 2008) studies found that nematode community structures and soil physicochemical characteristics were different between ORG and CONV , even in commercial fields. Some studies found that chemical herbicide and insecticide affected different nematode taxa in different manners (Neher and Olson, 1999; PenMouratov and Steinberger, 2005; Y ardirn and Edwards, 1998). As already mentioned, further studies should evaluate these chemical factors, and the soil physicochemical factors excluded in our study but probably related to farming systems, such as soil-aggregate size distribution, for their effects on nematode community structures in comparisons of ORG and CONV.

We believe that the farming systems affected nematodes by establishing different community structures in some aspects between ORG and CONV. However, it was also true that sand and silt contents of soil which were considered not to be directly related to the systems, sometimes had a significant effect on the community structures. A nother drawback of our study was the reduced number of ORG plots, especially in 2006. Thus, further studies should examine more ORG plots, preferably of the same soil type as CONV plots, to elucidate more clearly farming system effects on nematodes.

\section{ACKNOW LE DGMENTS}

We especially thank the tomato farmers and $Y$ uko Hasegawa (Fukushima Prefecture A gricultural Extension Center) for the soil sampling arrangements, Ikuo Kadota (National A gricultural Research Center for T ohoku Region, NARCT), Chikako Shimaya (National A gricultural Research Center for Kyushu Okinawa Region), Takakazu Miyoshi (Nishikyusyu University), Satoshi Shimano (Miyagi University of Education), and the members of the research support team at NARCT for soil sampling and processing.

\section{REFERENCES}

A rao, T ., Okano, S. and Kanamori, T . (1998) The analysis of phospholipid fatty acids of upland soils. Japanese Journal of Soil Science and Plant Nutrition 69, 47-52.

Bongers, T ., (1990) The maturity index: an ecological measure of environmental disturbances based on nematode species composition. Oecologia 83, 14-19.

Bongers, T . and Bongers, M. (1998) Functional diversity of nematodes. A pplied Soil Ecology 10, 239-251.

Bongers, T . and Korthals, G. (1993) T he Maturity Index, an instrument to monitor changes in the nematode community structure. Summaries of the 45th International symposium on crop protection, Gent, Belgium, 80.

Bossio, D. A ., Scow, K. M., Gunapala, N. and Graham, K. J. (1998) Determinants of soil microbial communities: effects of agricultural management, season and soil type on phospholipid fatty acid profiles. Microbial Ecology 36, 1-12.

Briar, S. S., Grewal, P. S., Somasekhar, N., Stinner, D. and Miller, S. A . (2007) Soil nematode community, organic matter, microbial biomass and nitrogen dynamics in field plots transitioning from conventional to organic management. A pplied Soil E cology 37, 256-266.

Bulluck III, L. R., Barker, K. R. and Ristaino, J. B. (2002) Influences of organic and synthetic soil fertility amendments on nematode trophic groups and community dynamics under tomatoes. A pplied Soil Ecology 21, 233-250.

Ferris, H. and Bongers, T. (2006). Nematode indicators of organic enrichment. Journal of Nematology 38, 3-12.

Ferris, H., Bongers, T. and de Goede, R. G. M. (2001) A 
framework for soil food web diagnostics: extension of the nematode faunal analysis concept. A pplied Soil Ecology 18, 13-29.

Ferris, H., V enette, R. C. and Lau, S. S. (1996) Dynamics of nematode communities in tomatoes grown in conventional and organic farming systems, and their impact on soil fertility. A pplied Soil E cology 3, 161-175.

Frostegård, A., Tunlid, A and Bååth, E. (1993) Phospholipid fatty acid composition, biomass, and activity of microbial communities from two soil types experimentally exposed to different heavy metals, Applied and Environmental Microbiology 59, 3605-3617.

Goralczyk, K. (1998) Nematodes in a coastal dune succession: Indicators of soil properties? A pplied Soil E cology 9, 465-469.

Jairajpuri, M. S. and A hmad, W. (1992) Dorylaimida: FreeLiving, Predaceous and Plant-Parasitic Nematodes. Brill Publishing, Leiden, $458 \mathrm{pp}$.

Liu, B., Tu, C., Hu, S., Gumpertz, M. and Ristaino, J. B. (2007) Effect of organic, sustainable, and conventional management strategies in grower fields on soil physi$\mathrm{cal}$, chemical, and biological factors and the incidence of Southern blight. A pplied Soil Ecology 37, 202-214.

Moser, T., Schallnaß, H. J., Jones, S. E., Van Gestel, C. A. M., Koolhaas, J. E., Rodrigues J. M. L. and Römbke, J. (2004) Ring-testing and field-validation of a terrestrial model ecosystem (TME) - an instrument for testing potentially harmful substances: effects of carbendazim on nematodes. Ecotoxicology 13, 61-74.

Mulder, C. H., Zwart, D. D. E., Van Wijnen, H. J., Schouten, A. J. and Breure, A. M. (2003) Observational and simulated evidence of ecological shifts within the soil nematode community of agroecosystems under conventional and organic farming. Functional Ecology 17, 516-525.

Neher, D. (2001) Role of nematodes in soil health and their use as indicators. Journal of Nematology 33, 161-168.

Neher, D. A . and Olson, R. K. (1999) Nematode communities in soils of four farm cropping management systems. Pedobiologia 43, 430-438.

Okada H., and Harada, H. (2007) Effects of tillage and fertilizer on nematode communities in a Japanese soybean field. A pplied Soil E cology 35, 582-598.

Okada, H., Harada, H. and Kadota, I. (2004) A pplication of diversity indices and ecological indices to evaluate nematode community changes after soil fumigation. Japanese Journal of Nematology 34, 89-98.

Pen-Mouratov, S. and Steinberger, Y. (2005) Responses of nematode community structure to pesticide treatments in an arid ecosystem of the Negev Desert. Nematology
7, 179-191.

R Development Core Team (2005) R: A language and environment for statistical computing. $R$ Foundation for Statistical Computing, Vienna, A ustria. ISBN 3-90005107-0, URL http://www.R-project.org.

Sekiguchi, H., Hasegawa, H., Okada, H., Kushida, A . and Takenaka, S. (2008) Comparative analysis of environmental variability and fungal community structure in soils between organic and conventional commercial farms of cherry tomato in Japan. Microbes and Environments 23, 57-65.

Takeda, M., Nakamoto, T ., M iyazawa, K., Murayama, T. and Okada, H. (2009) Phosphorus availability and soil biological activity in an Andosol under compost application and winter cover cropping. A pplied Soil Ecology 42, 86-95.

T aki, K. and Kato, T. (1998) Features of the soil in organic farming field, Research Bulletin of the Aichi-ken A gricultural Research Center 30, 79-87. (in Japanese with English summary)

T siafouli, M. A ., A rgyropoulou, M. D., Stamou, G. P. and Sgardelis, S. P. (2006) Soil nematode biodiversity in organic and conventional agroecosystems of Northern Greece. Russian Journal of Nematology 14, 159-169.

U rashima, Y., Nakajima, M., Kaneda, S., Okada, H., Hasegawa, H. and M urakami, T. (2009) Comparative analysis of phospholipid fatty acid composition between organic and conventional farming fields. Soil Microorganisms 63, 55-63. (in Japanese with English summary)

W all, J. W., Skene, K. R. and Neilson, R. (2002) Nematode community and trophic structure along a sand dune succession. Biology and Fertility of Soils 35, 293-301.

W ang, K. H., M cSorley, R., M arshall, A . and Gallaher, R. N. (2006) Influence of organic Crotalaria juncea hay and ammonium nitrate fertilizers on soil nematode communities. A pplied Soil E cology 31, 186-198.

Y ardirn, E. N. and Edwards, C. A . (1998) The effects of chemical pest, disease and weed management practices on the trophic structure of nematode populations in tomato agroecosystems. A pplied Soil Ecology 7, 137147.

Y eates, G. (1994) M odification and qualification of the nematode maturity index. Pedobiologia 38, 97-101.

Y eates, G. (2003) Nematodes as soil indicators: functional and biodiversity aspects. Biology and Fertility of Soils 37, 199-210.

Y eates, G. W . and Bongers, T . (1999) Nematode diversity in agroecosystems. A griculture, Ecosystem and Environment 74, 113-135. 
Y eates, G., Bongers, T., de Goede, R. G. M., Freckman, D. W. and Georieva, S. S., (1993) Feeding habits in nematode families and genera-an outline for soil ecologists.
Journal of Nematology 25, 315-331.

Received A pril 10, 2009 